\title{
North-South Research Partnership: Is Collaboration Possible between Unequal Partners ?
}

\author{
Jacques F. Gaillard
}

\begin{abstract}
Scientific cooperation between the Industrialized Countries (ICs) and the Less Developed Countries (LDCs) has evolved greatly over the last three decades and has involved a number of varied mechanisms ranging from technical assistance to collaborative research partnerships. After a brief historical review of these mechanisms and of the conceptual debates around them, this paper considers the main programs that have been established during the last 10-15 years to promote North-South scientific collaborative partnership. One of the main problems encountered in the implementation of collaborative research programs relate to the asymmetry of the collaboration and the dominance of the partners in the North. While recognizing that conditions for success may differ depending on the main objectives of the collaboration, a list of ingredients for successful collaboration is proposed in the conclusion. This is based on the experience of the programs under review.
\end{abstract}

\section{From Technical Assistance to North-South Research Partnership}

The variety of mechanisms and institutions created by Industrialized Countries (ICs) for promoting and supporting research activities in Less Developed Countries (LDCs) has evolved greatly over the last three decades. Chronologically (but with some overlap), the main mechanisms that have been used include: technical assistance, overseas training, institution building, institutional twinning arrangements and collaborative research partnerships.

Different mechanisms also exist to channel flows of resources to scientific and technological activities in LDCs:

- bilateral mechanisms used by most national aid agencies;

- multilateral mechanisms (UNDP and specialized agencies of the United Nations, the World Bank, and a variety of regional intergovernmental agencies such as the European Community, the Organization of American States, the Andean Pact and ASEAN);

Jacques F. Gaillard is a senior scientist at the Institut Français de Recherche Scientifique pour le Developpement en Coopération (ORSTOM), 213 rue La Fayette, 75010 Paris, France.

Knowledge and Policy: The International Joumal of Knowledge Transfer and Utilization, Summer 1994, Vol. 7. Number 2, pp. 31-63.

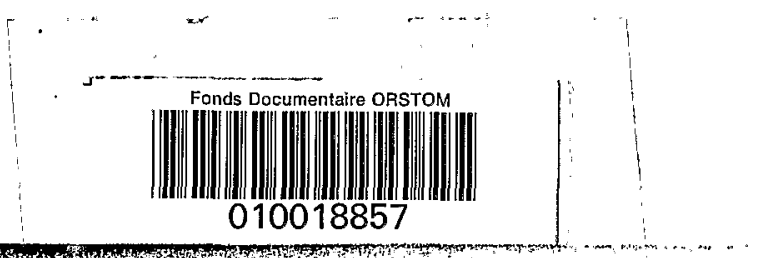

Fonds Documentaire OFSTOM Cote: $B * 18857$ Ex: 1 
- nongovernmental organizations (NGO) such as private foundations and other philanthropic institutions, international scientific societies granting programs (e.g., the International Foundation for Science (IFS) and the Third World Academy of Science (TWAS); and

- international support for specific activities, the model being the Consultative Group on International Agricultural Research (CGIAR). The possibility of using the same approach for other areas of development research is being considered.

The total volume of resources allocated is not well known. According to one of the most comprehensive studies available, carried out by the International Development Research Center (IDRC), the total resources for development-related research ranged between US $\$ 1.3$ to 1.4 billion per year in 1984. Today, it is estimated by IDRC at US $\$ 2$ billion (IDRC, 1991).

In the ICs, the differences in approach are correlated with vastly different historical backgrounds and political climates for foreign scientific and technical assistance (OECD, 1985). Countries such as France, the United Kingdom, the Netherlands, Belgium, Germany, Portugal and Spain have a long history of rendering scientific and technical assistance to LDCs. Most of the latter have created specialized scientific research institutes for the tropics, ${ }^{2}$ having specialized teams of research scientists, differing in size, that have acquired unique field experience. Starting from the 1950s and even more during the 1960s, U.S. involvement became significant and soon dominant. ${ }^{3}$ During the 1970s, countries that did not have a colonial past, such as Canada, Sweden and Australia, set up central institutions specialized in scientific and technological cooperation with the LDCs. ${ }^{4}$ Japan has also emerged as a major partner in S\&T cooperation for development mainly during the 1980 s.

As modalities of cooperation have evolved over time, the expectations for those ventures have also changed. During the $1950 \mathrm{~s}$ and $1960 \mathrm{~s}$, the primary objective was to find quick solutions to development problems, mainly through the mobilization of the IC's own scientific and technological resources (human and financial). This was the "problem solving" phase that somewhat overlapped with the "technical assistance" phase. It culminated during the 1960 s and early 1970s. During that period, "who did the problem solving, and how" was considered a secondary issue. The concept of endogenous capacity development (or capacity building) then emerged. It gained momentum in the 1970s when new institutions were created in Canada (IDRC) and Sweden (SAREC) to foster S\&T cooperation with developing countries. This concept was reaffirmed by the group of 77 at the UN Conference on Science and Technology for Development, organized in Vienna in 1979. The main purpose was to build problem solving capacities, i.e., research capacities in the recipient country. These two approaches (problem solving and capacity building) have long divided donor countries (Lewis, 1987: 12-13). At the same time, there was a gradual realization that the creation of effective research systems depends not only on human and financial resources. Other factors also of prime importance include the professional and social status of research personnel, adequate reward sys- 
tems, and the emergence and reproduction of socially recognized scientific communities.

Following the Vienna conference, the main donors seem to be converging somewhat on the way research collaboration with developing countries should be organized. This was partly due to the globalization of world economic interdependence, the internationalization of $S \& T$ issues, and increased competition. Mainstream rhetoric is now emphasizing the fact that support should generate new collaborative relationships that benefit both sides. This may also be due to the necessity to find new justifications to counteract the "aid fatigue" as experienced in a number of donor countries. Aiding research in collaboration and in partnership with developing countries is now presented as the principal means of enabling these countries to build problem-solving capacities and to face up to their development needs.

The main problems and discrepancies encountered in the implementation of collaborative research programs relate, as shown in this paper, to the asymmetry of the collaboration and the dominance of the partners in the North. Thus, concerns were expressed in many LDCs during the 1970 s about possible risks and abuses resulting from scientific collaboration, including scientific colonialism, indirect military exploitation, commercial exploitation of the research results by companies in ICs, and enhanced risks of brain drain. There has been much less concern expressed about the risks of collaboration during the 1980 s.

Many industrialized nations are now recognizing that aiding research in collaboration and in partnership. with developing countries is now one of the principal means of enabling these countries to build problem solving capacities and to face up to their development needs. The aim of this article is to review the main mechanisms and programs that have been established during the last 10-15 years to promote North-South scientific collaborative partnership. ${ }^{5}$

\section{North-South Scientific Collaborative Partnerships: A Review of the Main Programs}

The Vienna Program of Action, which was adopted at UNCSTD, urged that north-south cooperative research should bear a number of characteristics (UN, 1979). The most important of these were that they should:

- be in keeping with development priorities determined by developing countries themselves;

- provide, as far as possible, for developing country participation, even when conducted in developed country institutions;

- provide for joint participation and control, when conducted in developing countries; and

- include a training component.

The following addresses a number of questions about the programs under review. These include: How many of the UNCSTD recommendations 
have been implemented? What have been other possible influences behind the establishment of the programs under review? What are the main similarities and differences of the programs? What have been the main problems encountered? What lessons can we draw?

The choice of programs to be compared has been guided by the accessibility of information and the availability of internal or external evaluations. ${ }^{6}$ The programs considered include: The cooperative research program of the International Development Research center (IDRC), Ottawa, Canada; The partnership research programs of the Swedish Agency for Research Cooperation with developing countries (SAREC); The Collaborative Research Support Programs (CRSPS) of the U.S.A.I.D.; The Program in Scientific and Technological Cooperation (PSTC) of the U.S.A.I.D.; The Grants Program of the Board on Science and Technology for International Development (BOSTID) of the U.S. National Academy of Sciences; The U.S.-Israel Cooperation Development Program (CDR) of the U.S.A.I.D.; The Danish Program for Enhancement of Research Capacity in Developing Countries (ENRECA); The Science, Technology and Development Program (STD) of the European Community.

The main characteristics of the programs under review are summarized in Table $1 .^{7}$

\section{The Cooperative Research Programs of the International Development Research Center (IDRC), Canada ${ }^{8}$}

At UNCSTD in 1979, the government of Canada pledged that it would provide funds for "collaborative research" as sought-by the group of 77, representing all developing countries, and invited the International Development Research Center (IDRC) to serve as the focal point of the new activities. IDRC was created in 1970 to stimulate and support scientific and technical research in developing countries. Following a recent reorganization, "collaborative research" activities might be further strengthened within IDRC, while it is developing enhanced partnerships with Canadian institutions (IDRC, 1991).

The objectives of the IDRC partnership programs are broadly defined as follows:

- to develop the scientific and technological capacity of participating Third World institutions or groups by improving their opportunities for collaboration with the Canadian part of the international scientific community;

- to create channels of communication among scientists through which the results of successful research in Canada can be transferred to researchers in the Third World; and

- to influence the direction of Canadian research towards Third World concerns (IDRC, 1987).

From the beginning, IDRC was concerned about a possible dominance of the Canadian partners and took the position of only accepting proposals originating from or with developing countries, and rejecting those that originated solely from Canada. The newly redefined strategy of IDRC also out- 
TABLE 1

Main Characteristics of the Programs under Review

\begin{tabular}{|c|c|c|c|c|c|c|c|c|}
\hline & $\begin{array}{l}\text { Year of } \\
\text { creation }\end{array}$ & $\begin{array}{l}\text { Country } \\
\text { Eligibility }\end{array}$ & $\begin{array}{l}\text { Research } \\
\text { Priority } \\
\text { Areas }\end{array}$ & $\begin{array}{l}\text { Who are the } \\
\text { Grants } \\
\text { Recipients }\end{array}$ & $\begin{array}{l}\text { No. of } \\
\text { Projects } \\
\text { supported }\end{array}$ & \begin{tabular}{|l|} 
Average \\
Size of \\
Grants \\
\end{tabular} & $\begin{array}{l}\text { Sharing out of } \\
\text { Grants } \\
\text { betw. Partners }\end{array}$ & $\begin{array}{l}\text { Actual } \\
\text { Geographic } \\
\text { Coverage }\end{array}$ \\
\hline IDRC & $\begin{array}{l}\text { North-South Res. } \\
\text { Coop. became an } \\
\text { arca of emphasis } \\
\text { from } 1980^{l} \text {. }\end{array}$ & Canada and LDCs & $\begin{array}{l}\text { Agric.. Natural } \\
\text { Res., Health, } \\
\text { Socinl and Earth } \\
\text { Sc., Technology }\end{array}$ & $\begin{array}{l}\text { Cauhdian and } \\
\text { Developing } \\
\text { Country } \\
\text { Institulions }\end{array}$ & $\begin{array}{l}385 \text { projects } \\
\text { during } 1980-1992 \\
\text { involving } 72 \\
\text { Canadian lnst. }\end{array}$ & $\begin{array}{l}\text { USD } 95,000 \\
\text { per project for } \\
\text { iwo years }\end{array}$ & $\begin{array}{l}\text { slightly more } \\
\text { than } 50 \% \text { to } \\
\text { Partners in the } \\
\text { South }\end{array}$ & $\begin{array}{l}\text { Concentration in } \\
\text { Latin America } \\
\text { and Asia, Fewer } \\
\text { projects in Africa }\end{array}$ \\
\hline SAREC & $\begin{array}{l}\text { North-South Res. } \\
\text { Coop. became an } \\
\text { area of emphasis } \\
\text { from } 1982^{2}\end{array}$ & $\begin{array}{l}\text { Sweden and } \\
\text { LDCs }\end{array}$ & $\begin{array}{l}\text { Heal (h/Nutrition } \\
\text { Rural Dvt. } \\
\text { Environment } \\
\text { Tech./Indust. } \\
\text { Social Sc. } \\
\end{array}$ & $\begin{array}{l}\text { Swedish and } \\
\text { Developing } \\
\text { Country } \\
\text { Institutions }\end{array}$ & $\begin{array}{l}664 \text { projects } \\
\text { during 1982-1990 } \\
\text { involving } 124 \\
\text { Sivedish Inst. and } \\
\text { 211 Dev. C. Inst. } \\
\end{array}$ & $\begin{array}{l}\text { USD } 100,000 \\
\text { per year and pet } \\
\text { projoct }\end{array}$ & $\begin{array}{l}\text { close } 1060 \% \text { to } \\
\text { Partners in the } \\
\text { South }\end{array}$ & $\begin{array}{l}\text { Concentration in } \\
15 \text { countries. } \\
\text { Africa accounts } \\
\text { for } 55 \% \text { of } \\
\text { projects. }\end{array}$ \\
\hline CRSP & $\begin{array}{l}\text { the first CRSP } \\
\text { was established } \\
\text { in } 1978 \\
\end{array}$ & $\begin{array}{l}\text { U.S. and LDCs } \\
\text { as in A.I.D. list }\end{array}$ & Agriculture & $\begin{array}{l}\text { U.S. and } \\
\text { Developing } \\
\text { Countries Inst. }\end{array}$ & & $\begin{array}{l}\text { USD } 200,000 \\
\text { per year and per } \\
\text { projoct. }\end{array}$ & $\begin{array}{l}\text { at licast } 50 \% \text { to } \\
\text { partners in the } \\
\text { South }\end{array}$ & $\begin{array}{l}13 \text { counlries in } \\
\text { Africa, } 10 \text { in } \\
\text { Asia and } 3 \text { in LA }\end{array}$ \\
\hline PSTC & 1981 & $\begin{array}{l}\text { LDCs with U.S. } \\
\text { ADCs coll. also } \\
\text { allowed }\end{array}$ & $\begin{array}{l}6 \text { areas related to } \\
\text { biology and } \\
\text { biological res. }\end{array}$ & $\begin{array}{l}\text { U.S. and } \\
\text { Developing } \\
\text { Country Inst. }\end{array}$ & $\begin{array}{l}498 \text { projects } \\
\text { during } 1981-1992\end{array}$ & $\begin{array}{l}\text { close to USD } \\
150,000 \text { per } \\
\text { project }\end{array}$ & $\begin{array}{l}\text { at least } 50 \% \text { to } \\
\text { partners in the } \\
\text { South }\end{array}$ & $\begin{array}{l}39 \% \text { Asia, 35\% } \\
\text { LA, 17\% Africa, } \\
6 \% \text { Near East. } \\
3 \% \text { East. Europe }\end{array}$ \\
\hline BOSTID & 1981-1988 & LDCs & $\begin{array}{l}6 \text { very narrowly } \\
\text { defined research } \\
\text { areas } 3\end{array}$ & $\begin{array}{l}\text { Developing } \\
\text { Countries Inst. }\end{array}$ & 107 projects & \begin{tabular}{|l|} 
close to USD \\
150,000 per \\
project for 3 or 5 \\
years
\end{tabular} & $\begin{array}{l}\text { the totality of the } \\
\text { grant goes to } \\
\text { Developing } \\
\text { Country Inst. }\end{array}$ & $\begin{array}{l}46 \% \text { LA. } \\
37 \% \text { Asia and } \\
17 \% \text { Arrica }\end{array}$ \\
\hline CDR & 1985 & $\begin{array}{l}\text { Israel with LDCs } \\
\text { ADCs coll. also } \\
\text { allowed } \\
\end{array}$ & $\begin{array}{l}\text { arid agriculture, } \\
\text { biology, energy, } \\
\text { water res. manag. }\end{array}$ & $\begin{array}{l}\text { Israeli and LDC } \\
\text { institutions }\end{array}$ & $\begin{array}{l}151 \text { projects } \\
\text { during } 1985-1992\end{array}$ & $\begin{array}{l}\text { close to USD } \\
200,000 \text { per } \\
\text { projecl }\end{array}$ & $\begin{array}{l}50 \% \text { to partners } \\
\text { in the South }\end{array}$ & $\begin{array}{l}35 \% \text { Asia, } 31 \% \\
\text { Africa, } 27 \% \text { LA, } \\
7 \% \text { East. Europe }\end{array}$ \\
\hline ENRECA & $\begin{array}{l}\text { 1988, became } \\
\text { operational in } \\
\text { Docember } 1989\end{array}$ & \begin{tabular}{|l|} 
Denmark and \\
Countries with a \\
GNP per capita \\
lower than 1,700 \\
\end{tabular} & $\begin{array}{l}\text { Broad list of } \\
\text { development } \\
\text { oriented topics }\end{array}$ & $\begin{array}{l}\text { Danish and } \\
\text { Devcloping } \\
\text { Countries Inst. }\end{array}$ & \begin{tabular}{l|}
24 projects \\
during $1989-1992$
\end{tabular} & $\begin{array}{l}\text { USD } 450,000 \text { per } \\
\text { project for } 3 \\
\text { years . : }\end{array}$ & $\begin{array}{l}\text { at least } 50 \% \text { to } \\
\text { Partners in the } \\
\text { South }\end{array}$ & $\begin{array}{l}3 / 4 \text { of the active } \\
\text { projects are in } \\
\text { Africa }\end{array}$ \\
\hline STD/CEC & 1983 & $\begin{array}{l}\text { European } \\
\text { Countries and } \\
\text { LDCs }\end{array}$ & $\begin{array}{l}\text { Agriculture, } \\
\text { Health and } \\
\text { Nutrition }\end{array}$ & $\begin{array}{l}\text { Europcan } \\
\text { Counlry and } \\
\text { LDCs Inst. }\end{array}$ & \begin{tabular}{l|}
797 projects \\
during 1983-1991
\end{tabular} & $\begin{array}{l}\text { USD } 300,000 \text { per } \\
\text { project for } 3-4 \\
\text { years }\end{array}$ & $40 \%$ & $\begin{array}{l}53 \% \text { Arrica, } 20 \% \\
\text { LA, } 16 \% \text { Asia } \\
\text { and } 12 \% \text { Medil. }\end{array}$ \\
\hline
\end{tabular}

1. IDRC was established in 1970.

2. SAREC was established in 1975.

3. Grain amaranth, biological nitrogen fixation, tropical fast-growing trees, mosquito vector research, rapid epidemiological assessment and acute respiratory infection in children. 
lines that partnership research activities "should look beyond the traditional concept of North-South technical assistance and asymmetry, and should focus on the mutual interests of Canada and Developing Countries" (IDRC, 1991).

In the first two years of its existence, $(1981 / 82,1982 / 83)$, the Collaborative Programs (CPs) Division (then a Unit), promoted research collaboration between groups in Canada and those in the developing countries, covering all disciplines that contribute to the socioeconomic development of developing countries and that fall outside the program areas of other divisions of the Center. This arrangement gave the necessary flexibility to better respond to the developing countries priorities. At the same time, a more structured approach providing better access to Canadian competence was adopted to respond more effectively to the demand. The creation of the programs for Earth Sciences (1983/84), Technology for Local Enterprises $(1985 / 86)$ and Building Industry, Materials and Technologies is the result of this approach.

Since 1983, the CPs budget has been divided between (1) funds to be used by the Center's established program divisions ${ }^{9}$ for cooperative research activities falling within their areas of competence and (2) funds to be used in support of new ventures in areas of research not primarily supported by the Center. The growth of the CPs has been quite substantial in a relatively short period of time: from 5 percent of the overall IDRC budget in 1982 to about 20 percent in 1987. During the last years, the Center has been committing about 18 percent of its program budget-on Canadian cooperative initiatives. Despite this remarkable growth, the CPs level of funding has not (yet) reached the level of 1 percent of Canadian ODA pledged in 1979 at UNCSTD. The main types of activities most frequently supported as reviewed by Asibey include: "institutional strengthening and training; building research networks between Canadian and LDC researchers and among LDC researchers; improving research management capacities; facilitating technology transfer and application; and applying Canadian research expertise on specific research problems" (Asibey, 1992: 18).

During 1980/92, IDRC support to cooperative activities totalled over Cd $\$ 47$ million for 385 projects, i.e., Cd\$ 122,000 (or about US\$ 95,000) on average per project $t^{10}$ and for one phase of two years. Close to half of the appropriated funds ( $\mathrm{Cd} \$ 22.7$ million or 48.3 percent) went to Canadian research institutions and universities. A total of 72 Canadian institutions have participated in the IDRC partnership program. Of these, universities and colleges have received far more than any other category (i.e., 54 percent). In the South, most support went to institutions in Latin America, Caribbean and Asia. Most of the projects in the South are located at national institutions ( 89 percent), followed far behind by regional ( 23 projects, 7 percent of the funds) and international institutions ( 14 projects, 3 percent of the funds). Universities and research institutions in Latin America and the Caribbean (mainly in Chile, Colombia, Peru, Jamaica, Argentina, Costa Rica and Mexico) are the largest recipient (with $\mathrm{Cd} \$ 11.3$ million or 24 percent). They are followed by institutions in Asia (mainly China, Thailand, 
:ional

iould

DRC,

ative

ation

ering

evel-

sions

ar re-

truc-

was

$f$ the

rises

esult

o be

arch

used

$\mathrm{d}$ by

vely

32 to

om

itive

has

79 at

; re-

iild-

ong

ting

ex-

iver

I on

the

lian

ons

ties

ser-

ica,

na-

cts,

ent

ind

ista

ier-

nd,

India, Malaysia and Singapore) with an overall share of Cd\$ 5.9 million or 12.6 percent. Sub-Saharan Africa (mainly Tanzania and Senegal) received only Cd $\$ 3.4$ million or 6.9 percent and the Middle East region (mainly Syria ${ }^{11}$ ) only Cd\$ 2.5 million or 5.3 percent (Asibey, 1992: 21-26).

Some of the main characteristics, findings and discrepancies uncovered during the first years of operation, and reported in IDRC (1987), are summarized below.

The number of proposals originating from developing countries or jointly submitted with a Canadian partner has been rising steadily. In 1984/85 68 percent of all proposals originated from or with (joint) developing countries and 32 percent from Canada alone. Programs for which the discipline scope is clearly defined, e.g., Earth Sciences, resulted in a higher developing country and joint submissions than other programs did.

Although cooperative support is demand-driven by the requests from developing countries, it was soon realized that it must be driven by demand and Canadian competence together. It was also clear that identifying and developing access to Canadian competence takes time: Universities are by far the most important Canadian Partner category.

The need for collaboration depends on country and research institution. In general, it was found that having a Canadian partner was an essential need for developing country scientists, particularly in Africa. Even with the often better research infrastructure in Asia or Latin America, researchers desire a Canadian partner and perceive it as their best access to more advanced technologies and know-how.

The division of the grant between the partners is a useful indicator for the degree of collaboration. The norm is that partners must share the grant "fairly." At present, close to 50 percent of the grant is used by the partners in the south. The guidelines stress that genuine collaboration and access to Canadian capabilities is secured, and that research results are shared and become common knowledge and property amongst partners. The IDRC cooperative research programs are being evaluated and the results should be available towards the end of $1993 .{ }^{12}$

\section{Research Cooperation between Institutions in Developing Countries and Sweden (SAREC) ${ }^{13}$}

Started on a very modest scale more than a decade ago, twinning research programs between Swedish and Developing Countries research institutions (or "Bilateral Research Cooperation") have become one of the main activities of the Swedish Agency for Research Cooperation with Developing Countries (SAREC). Established in 1975 to promote research efforts that contribute to the development of the Third World countries, SAREC has defined three main operational aims (Bhagavan, 1992: 9-10):

- to assist developing countries in building up their own research capacity in the form of good research environments, training of researchers, as well as methods for planning of, setting priorities in and allocating resources to, research; 
- to provide developing countries with financial and scientific resources to generate research results in areas that are important to their development; and

- to assist developing countries, if the need arises, in establishing scientific contacts and cooperation with international and Swedish institutions.

Strengthening research capacities in developing countries is the key concept in SAREC's policies and programs. Of its four major programs, ${ }^{14}$ the "Bilateral Research Cooperation," which comprises mainly scientific collaborative projects between Swedish and Developing Country Institutions accounts today for roughly one-third of the annual research allocation of nearly SEK 400 million (approx. US $\$ 55$ million). A total of 211 developing country institutions and 124 Swedish institutions had participated in the program by 1990 . The total annual allocation for this program was close to US $\$ 15$ million in 1990 for 169 projects (i.e., slightly less than US\$100,000 annually per project in average) distributed in fifteen developing countries only. Africa (mainly Zimbabwe, Ethiopia, Mozambique, Tanżania and Somalia) accounts for about 55 percent of the total number of projects, Latin America (mainly Nicaragua, Argentina and Cuba) for about 28 percent and Asia (mainly Sri Lanka and Vietnam) for the remaining 17 percent. While the average total annual cost per project in 1990 was approximately US\$ 100,000 for Africa, it was about ten percent higher for Latin America and for Asia. The projects are distributed rather evenly in the four operational research areas ${ }^{15}$ except for the social sciences, which receive the lowest share. ${ }^{16}$

The institutional cooperation within the SAREC bilateral cooperation program has been evaluated by two swedish external consultants during 1989-90 based on 71 projects, i.e., roughly half the number of institutional cooperation projects in operation during 1988/89. The developing country project leaders interviewed expressed unanimously their satisfaction with the program. The evaluators also found that "SAREC support has had a beneficial impact on the research capacity of the recipient countries" and that "the SAREC model has served to increase Swedish interest in research in developing countries as well as to increase Swedish knowledge about the problems of research in developing countries" (Bhagavan, 1992: 29-30). The main problems and shortcomings uncovered, as summarized by Bhagavan (1992: 29-34), are given below:

- The volume of output measured in scientific reports and published work was found to be in general unsatisfactory with the exception of cooperation with the scientifically more advanced developing countries. Swedish counterparts have also assumed the major part of the work and responsibility in producing the papers published in international journals, conference proceedings, and books.

- On an average, support to the developing country institutions accounts for slightly less than $60 \%$ of the total. This was found to be too little by the evaluators who argued that it should be possible to relocate certain activities from the Swedish to the developing country institution. Standard laboratory analysis is given as an example. 
?n-

fic

n-

he

sl-

ns

of

ig

ie

to

30

es

$\mathrm{D}-$

in

Id

le

i\$

rr

$3-$

16

n

$\mathrm{g}$

II

$\mathrm{y}$

h

a

d

h

it

1.

y

k

2

$-$

(

r

3

- The main administrative problems encountered by the projects are the delays and uncertainties in the receipt of funds by the developing country institutions. Other severe administrative problems are associated with the procurement of equipment, spare parts, consumables and literature from abroad, as well as purchase of air tickets and subsidies for foreign travel. While project administrators and/or leaders have often found ad hoc ways of solving these problems, the evaluators urge that standardized procedures be more strictly followed in the future.

- As a matter of policy, SAREC does not at present contribute to the salaries of developing country personnel. The main rationale behind this policy is the following: research is a priority for a developing country, that should be translated into adequate salaries for its nationals engaged in research work. The evaluators were very critical of this policy and strongly recommended SAREC to either face up the need to support the researcher financially or else "to pull out from countries where researchers' salaries are below the minimum real wage for the social strata in question."

- Despite the increase of interest within the Swedish-scientific community, the resource base that is available in Sweden for research cooperation with developing countries remains rather narrow in terms of both scientific disciplines and the number of Swedish researchers.

The latter point is considered crucial by SAREC, which acknowledges that the number of scientists actively involved on one or both sides is extremely small and that the question of size and vulnerability of groups should be reviewed:

It is not uncommon to find projects where the Swedish side consists of one professor and/or one associate professor, while the other side fields one or two pre-doctoral candidates.... There are examples of projects which despite several years of generous financial support have been unable to increase the number of participants beyond the original one or two; here clearly no research capacity is being built. And there are examples where with the withdrawal of the only senior person on either side, the projects collapsed (Bhagavan, 1992:38).

Another matter of concern is the problem of asymmetry between the Swedish side usually led by a senior scientist of proven experience and the developing country side with the project leader being sometimes himself at the level of undergoing research training. Under such asymmetrical conditions,

it is almost inevitable that the Swedish side should find itself slipping into the role of deciding what, how and when things should be done in the project, with the other side having to defer willy nilly to the "superior experience and wisdom" of the Swedish side (Bhagavan, 1992:42). 


\section{Research Cooperation between Institutions in Developing Countries and the United States}

Among the programs established to promote research collaborations between the United States and developing countries' institutions, one, the collaborative Research Support Programs (CRSPs) was created in the late 1970 s, and most of the programs became operational in the early 1980s, in response to Title XII of the Foreign Assistance legislated in 1975. It will be presented in more detail later.

Proposed by the Carter administration at UNCSTD in Vienna in 1979 as the masterpiece of U.S. presentation, the Institute for Scientific and Technical Cooperation (ISTC) was to be created as a new, small, semi-autonomous agency within the framework of the International Development Cooperation Agency (IDCA). ISTC was to foster and support science and technology cooperation between U.S. scientists and developing country counterparts. ISTC was however opposed by the Congress who didn't want to create a new government agency in addition to the U.S. Agency for International Development (A.I.D.) and probably also by key A.I.D. managers "who wanted undivided authority and responsibility" (Weiss, 1992). Congress failed to appropriate funds for the institute, and although officially established, it never came into being. Nevertheless, it was increasingly clear to Congress and others that some new mechanisms were needed to support research in developing countries, which would involve a strengthened scientific cooperation with the U.S. scientific community. Although Congress did not support the ISTC as a new entity, it did support many of the ISTC principles, and so directed the United States to establish a program for scientific cooperation and research with developing countries. A new position of Science Advisor to the AID Administrator was created and his office organized and managed the Program in Scientific and Technological Cooperation (PSTC). Funding was also provided for the Board on Science and Technology for International Development (BOSTID) to establish a program officially called Application for Science and Technology (more than half of this funding was to be used for research grants to developing countries institutions). In 1985, the U.S. Congress set aside US\$ 2 million to implement a new A.I.D. initiative: the U.S.-Israel Cooperative Development Research Program (CDR). All these activities are described in more detail below.

\section{The Collaborative Research Support Programs (CRSPs)}

In 1975, Congress passed the International Development and Food Assistance Act. Title XII of this Act, entitled "Famine Prevention and Freedom from Hunger," supported the creation of long-term collaborative research programs on food production, distribution, storage, marketing and consumption between U.S. Land Grant agricultural universities and institutions in the developing world. In addition to creating linkages between scientists in the United States and in developing countries, the goals of these 
programs were to foster institutional growth and promote training of scientists and technicians in developing countries. This act is the legislative foundation of the CRSPs (Yohe et al., 1990).

Between 1977 and 1982, the Joint Research Committee of the Board for International Food and Agriculture Development, which advises A.I.D. on university involvement in cooperative research, helped design and implement eight CRSPs. The CRSPs have since evolved into entities involving U.S. universities, A.I.D. and its regional bureaus and overseas missions, other U.S. federal agencies, national agricultural research systems in developing countries, international agricultural research centers, private agencies and industries, and developing country universities and other institutions (Yohe et al., 1990). The eight CRSPs have been established between 1978 and 1985. They are conducting research on: Small ruminants, (SR-CRSP), 1978; Sorghum/Millet, (INTSORMIL), 1979; Bean/Cowpea, (BCCRSP), 1980; Tropical soil management; (TROPSOILS), 1981; Peanut, (PCRSP) 1982; Pond dynamics/aquaculture (PDA-CRSP), 1982; Nutrition, (N-CRSP), 1982; Fisheries stock assessment, (FSA-CRSP), 1985.

In response to growing awareness of the importance of sustainable international development strategies, the U.S. Congress has recommended that A.I.D. create a new CRSP that focuses on the research needs of sustainable agriculture. A ninth CRSP on Sustainable Agriculture and Natural Resource Management (SANREM) was created in 1992 following the publication of a report by a Panel convened by the National Research Council whose conclusions were published in 1991 (NRC, 1991).

The first eight CRSPs programs involve more than 700 scientists from 38 U.S. universities on the one hand and research institutes and universities in some 26 developing host countries on the other. ${ }^{17}$ Geographically, the distribution of institutions shows a concentration in Africa (13 countries-primarily Senegal, Niger, Mali and Kenya), and to a lesser extent in Latin America (10 countries-mainly Brazil and Mexico) while only three countries in South East Asia (SEA) have hosted CRSPs programs (Thailand, Indonesia and Philippines). Some CRSPs are much more active in certain regions than others. For example, INTSORMIL is active mainly in Africa while Fisheries stock assessment-CRSP tend to concentrate its activities in South East Asia.

Each CRSP has a Management Entity (ME) and a Program Director usually based in a U.S. university, as well as an A.I.D. Project Officer based in Washington, D.C. The ME receives the grant from A.I.D. for implementing the Programs. It is legally responsible for the CRSP. A management Office (MO) must be established by the ME as the executive entity of the CRSP. The projects of the CRSP are funded and organized through subcontracts to U.S. lead institutions. These lead institutions, in turn, subcontract further with other approved U.S. institutions participating in the projects and the host country partner institutions in developing countries. The CRSP management is supported by three advisory groups: the Board of Directors (the policy-making body), the Technical Committee, and the External Evaluation Panel. The External Evaluation Panel annually assesses the re- 
search and training progress of the CRSP, both at U.S. and host country institutions.

Each project is organized under the management of a U.S. Principal Investigator (PI). In the host country, a counterpart PI is named to be responsible for project collaboration and host country activities. At least half of the A.I.D. funds for support of projects is to be spent in or directly on behalf of Host Countries in order to insure CRSP focus on the solution of Host Country problems rather than on the maintenance of existing research programs of U.S. institutions. It is estimated that the average yearly budget for each project is approximately US $\$ 200,000 .{ }^{18}$ The U.S. institutions must provide part of the funding needed. Contributions from the participating host country institutions are also encouraged.

The accomplishments of the CRSPs programs are quite extensive in terms of research and training outputs and impacts. The research contributions are reported in great details in each CRISPs progress annual reports and other documents (e.g., cf USAID, 1990; CRSP Council, 1991). The scope of this paper does not allow for a full description of these accomplishments. ${ }^{19}$ The CRSPs are plagued by two internal problems. First, while they are supposed to be collaborative in nature, one of the requirements of A.I.D. is that they operate in the world's poorest nations. Not surprisingly, these nations have often few or no scientists with whom American scientists might collaborate. Thus, the scientists involved often do not work in a truly collaborative mode. Both A.I.D. and external observers acknowledge that, most often, the "basic research" component of the program is taking place in the United States, while the Host Country is responsible for execution tasks (data collection, field experiments,...etc.) and, in general, more appliedoriented research activities.

Second, CRSPs are supposed to be interdisciplinary in character. Both natural and social scientists are to be represented. The involvement of social scientists from the start is considered as a novel aspect of the CRSPs (Mc Corkle, 1989). Only in this way, it has been argued, can the research achieve the critical mass necessary to move it from the research station to. the farmers' fields. Yet, LGUs do little domestic interdisciplinary research (Busch and Lacy, 1983). Therefore, CRSPs all too often simply divide the available funds among the various disciplines rather than develop truly interdisciplinary programs.

Another dilemma faced by the CRSPs, is internal to the A.I.D. organization: U.S. missions located in developing countries often view them as a threat. First, they require funds that would otherwise be in mission budgets. Second, teams of scientists associated with CRSPs take the time and resources from U.S. missions, that otherwise would be spent in developing mission projects. Thus, some missions have blocked CRSPs from operating. At their inceptions, CRSPs also tended to attract scientists who saw them as significant sources of funds, but who had only a minor interest in international work. They also required time to mature such that the scientists involved learned how to cooperate with their counterparts in Third World. In recent years many of these problems have however been rectified 
by better review procedures involving scientists from the developing countries (Gaillard and Busch, 1993).

\section{The Program in Scientific and Technological Cooperation (PSTC) ${ }^{20}$}

As mentioned earlier the idea to establish PSTC took shape during the U.S. preparation for UNCSTD in 1979. It was acknowledged that the United States needed a more innovative and more collaborative program to provide research support to Developing Countries. Despite (or as a consequence of) its failure to appropriate funds for ISTC, Congress mandated creation of the PSTC in 1981. It is administered by the Office of the Science Advisor within A.I.D.

The PSTC provides research grants in six priority areas (or research modules): Biotechnology/Immunology; Plant Biotechnology; Chemistry for World Food Needs; Biomass Resources and Conversion Technology; Biological Control; Diversity of Biological Resources. The definition of these modules has been very much influenced by BOSTID. The publication, "Priorities in Biotechnology Research for International Development," published by BOSTID in 1982 became the basis for three PSTC research modules: biomass resources, biotechnology/plants, and biotechnology/immunology. About US $\$ 1$ million is available annually for each module. It is the first program within A.I.D. to be based on a highly competitive process with external scientific peer review. The maximum budget for each project including all participants and overhead is US\$150,000. Investigators may be from universities, government laboratories or the private sector. Government laboratories that receive grants are required to provide at least 25 percent matching funds. PSTC also support collaborative research involving international research centers. Highest priority is given to scientists in developing countries receiving development assistance from the A.I.D. ${ }^{21}$ Cooperation with U.S. scientists is strongly encouraged, but not required. The grants competition is also open to investigators from the U.S. and from middle-income countries, such as Argentina, Brazil, Colombia, Korea, Malayșia, Mexico, Venezuela. However such proposals must be particularly innovative and involve strong scientific collaboration with scientists from LDCs. Thus, United States and middle-income country applicants must briefly describe their collaboration with LDC scientists and identify each participant's substantive role in the proposed research. PSTC does not support research involving China, or research taking place in a developed country. ${ }^{22}$ Research involving Israel is funded by other programs such as the U.S. Israel Cooperative Development Research Program (see below).

The number of preproposals submitted to PSTC has increased from just over 100 in the first year, to more than $600 .{ }^{23}$ Annually 120 are invited to prepare full proposals for external PSTC review. Around half of these are recommended for approval, but current budget levels allow only about 40 grants to be awarded. In its first year, PSTC awarded 75 percent of its grants to U.S. scientists and 25 percent to Third World Scientists. But by 1989, these numbers were reversed. Over the life of the program, 58 percent of the grants 
have been awarded to scientists in developing countries and 42 percent to U.S. scientists collaborating with colleagues in the Third World. The size of the grants per projects varies from a few thousand US $\$$ to 400,000 US $\$$ with an average around US\$150,000.

Of the 268 grants awarded between 1985 and 1990, 109 (40 percent) have been approved for projects in Asia, with a massive concentration in Thailand where not less than 48 projects are located ${ }^{24} ; 81$ ( percent) have been approved for projects in Latin America, with a concentration in Costa Rica, Brazil, Chile and Mexico; and 46 (17 percent) in 18 African countries, with some concentration in Kenya and to a lesser extent in Zimbabwe, Sudan and Egypt).

The PSTC has been evaluated on different occasions. The two first evaluations carried out in 1985 and 1988 were internal to A.I.D. PSTC was considered globally positive: "well conceived, well managed, and innovative." The 1988 evaluation stressed however that "there was room for improvement in the monitoring of grants, and more could be done to reduce management overhead and to provide support and training services to collaborators." In response to the review, PSTC arranged with BOSTID to provide such support and training. PSTC has also implemented better grant monitoring procedures, including the preparation of a streamlined manual explaining how to administer PSTC grants more efficiently. Also in 1988, external evaluations were conducted to measure the impact of PSTC grants on individual countries. It was concluded that "a majority" of PSTC grants "have had at least a moderate effect on capacity strengthening." Over the past five years, evaluation of the scientific work in four of the six main research areas of PSTC have been commissioned and conducted by external experts for three of them. Projects in all four areas received generally high marks. The evaluation report for the PSTC health/Biotechnology projects states that "the projects have produced state-of-the-art research resulting in internationally read publications and subsequent research funding opportunities" (USAID, 1992:54).

In one of the evaluation reports, the reviewers look into the question of U.S.-LDC collaboration. Although considered generally effective, it was found that the U.S. role in the collaboration was too dominant: "the U.S.LDC collaboration is leaning too much toward U.S. involvement" (Chrusciel, 1988: 70). According to the same evaluation, two characteristics of the PSTC were believed to limit collaboration between LDC and U.S. researchers. The first was related to the size of the grant and the second to the question of collaboration between unequal partners:

While US $\$ 150,000$ is considered a substantial sum in a developing country, it can not cover nearly as much researcher time in the U.S. Therefore, if U.S. scientists are paid any more than a token amount of their time, their is not much money left for the LDC researchers. Another problem for U.S. researchers was that collaboration with LDC researchers was not seen as a help to their career plans. Rather, involvement in a program of this type was probably more of a hindrance if they intended to stay in a competitive research environment (Chrusciel, 1988: 71). 
sent to size of \$ with

) have IThai2 been a Rica, i, with Sudan evalus conative." orove: manzes to CID to ' grant lanual 1988, grants jrants er the main extererally ology iearch fund-

ion of $\mathrm{t}$ was U.S.isciel, PSTC s. The ion of

itry, it S. scimuch 's was zareer e of a iment
Delays between submission of a proposal and approval of a project were also find to be sometimes quite lengthy. While two years is considered as the "normal" time frame by the program officers, some unusual (although rather frequent) situations may extend it to three or even more years. Interviews with U.S. principal investigators also revealed that, most of the time, "the idea for the projects originated with the U.S. researchers" (Chrusciel, 1988:129). However, there appears to have been a great deal of improvement over time (USAID, 1992:47).

It is also important for PSTC to demonstrate that solving development problems in the Third World also benefits the United States. Several examples are given in the A.I.D. material presenting the PSTC program after a decade of operation. As a way of illustration, antibacterial synthetic genes developed through PSTC-funded collaboration between CIP in Lima, Peru, and Louisiana State University produced a protein, which is toxic to a broad spectrum of bacteria that damages tens of millions of dollars worth of U.S. potatoes each year (USAID, 1992:38).

\section{The Grants Program of the Board on Science and Technology for International Development (BOSTID) ${ }^{25}$}

Between 1981 and 1991, the Board on Science and Technology for International Development (BOSTID), a major division of the National Academy of Sciences (NAS) complex, organized and managed a program for support of research projects in developing countries. To that end, BOSTID signed a grant agreement with A.I.D. in January 1981, for a five-year US\$36 million program officially called Application of Science and Technology to Development. Out of the US $\$ 36$ million, US $\$ 16.3$ million were to be used for research grants to developing countries institutions.

The BOSTID Research Program had four main objectives (Greene, 1991:4):

- To help developing countries strengthen their capability to deal with important development-related problems and move toward greater scientific and technological self-reliance;

- To stimulate and support research and development in developing countries on problems of high priority for development and human welfare;

- To provide developing countries with greater access to the scientific and technological knowledge and expertise that exists in the United States and other countries; and

- To provide a focus within the U.S. scientific and technical communities for assistance to the developing countries, and to encourage greater interaction with colleagues in the Third World.

Five criteria were used by the Committee on Research Grants (CRG) of BOSTID to select research areas (Greene, 1991:10):

- Importance to International Development.

- Advantage of carrying out the work in a developing country for ecological, environmental, or other reasons, and the likely presence of some capability and existing research facilities in the countries. 
- Likelihood of achieving significant progress in a short time, with technical assistance and technology transfer by U.S. scientists and engineers.

- Absence of substantial funding from other international donors.

- Prior experience of BOSTID and the role of BOSTID publications in elucidating the importance of the problem. ${ }^{26}$ This fifth criterion did not apply in practice for some of the health-related areas.

Research grants were offered in six technical areas: grain amaranth, biological nitrogen fixation, tropical fast-growing trees, mosquito vector research, rapid epidemiological assessment and acute respiratory infections in children.

The BOSTID program was characterized by several features:

- Grantees were selected on a competitive basis, with peer reviews of proposals and staff visits to applicants, to evaluate capability and assist with response to reviewers' comments on proposals.

- Staff were heavily involved in site visits, technical assistance, equipment procurement, financial management, and publication assistance.

- U.S. researchers participated as advisors, site visitors, and reviewers, and were also utilized for short-term training.

- Annual coordination meetings of grantees and advisors were held to report on research progress, discuss problems, and learn new techniques in hands-on workshops.

In addition, the BOSTID program had the ability to award grants to institutions in advanced developing countries, when the research would benefit developing countries in general. The country eligibility criteria were defined by BOSTID as "non-OECD, non-Eastern Block, non-Israel and nonSouth Africa" (Greene, 1991:17). Thus grants were given in countries such as Mexico, Brazil, Argentina, Chile, Malaysia, and Colombia, which otherwise received little assistance from the United States. Although potentially eligible, no grants were made to scientists from the Newly Industrialized Countries (NICs). The most controversial country to be excluded from eligibility for grants was the United States. This was considered by some U.S. scientists as a serious weakness of the program. Yet; BOSTID felt strongly that each project should have United States or other collaborators from a scientifically advanced country. If a grantee did not identify or request a collaborator in the proposal, the staff helped to identify appropriate individuals and added the costs for collaborative visits to the grant budget. Projects were visited about once a year, and the consultants' reports formed an important part of the evaluation process and of the project guidance.

Between 1981 and 1988, 564 proposals were received from developing country researchers; 107 grants were awarded, with an average research budget per grant of nearly US $\$ 150,000$ for three or five years. Forty-nine of the grants went to 16 Latin American countries including Mexico, Guatemala, Brazil and Chile, 40 to Asian countries mostly in Thailand and the Philippines, and the remaining 18 to African countries (out of which one third-went to Kenyan scientists ${ }^{27}$. The research grants resulted in the publication of more than 300 journal articles or book chapters. 
lical

uci-

$y$ in

bio-

re-

ons

rro-

vith

tent

and

re-

$s$ in

sti-

en-

ere

on-

Ich

ier-

ully

sed

eli-

I.S.

zly

a a

$\mathrm{ta}$

di-

,et.

ed

ng

ch

of

te-

he

ne

lb-

Two evaluations of BOSTID's granting program were carried out. The first internal evaluation was carried out in 1984 by three members of the Board of BOSTID (Burris et al., 1985). The report, while admittedly describing an early stage in the program, concluded that the program had reached all of its four main objectives (cf. above the four main objectives). The evaluators also made a number of suggestions:

- more emphasis should be put on linking research to utilization of research results and applicants should be asked about implementation plans in their research proposals;

- the participation of scientists of "high repute" from developing countries as advisors, reviewers, and consultants should be increased;

- the institution building aspects should be strengthened by including training and networking for other members of the research groups apart from the principal investigators;

- new research areas should be added to the program (an idea that A.I.D. opposed as premature).

A few months later, A.I.D. asked its Research Advisory Committee to carry out an evaluation of the BOSTID research program. The report was submitted in January 1986. The evaluation panel, while recognizing that the program was well managed and well designed, and that the grantees were well selected, was more critical than the first one. The evaluators felt that two main objectives of the program (i.e., support to good science and enhancement of scientific capacity in developing countries) were not well understood and accepted by those associated with the program. They also recommended increased participation of U.S. scientists, both for site visits and as collaborators in the research, and more use of the Academy resources.

The following year, Congress cut US\$ 2 million from the budget of the Office of the Science Advisor of A.I.D. for 1988. It was also made clear that the amount granted to BOSTID could not exceed US\$2 million, although the expected amount for 1988 was US\$ 4.5 million. The reason given was "the failure of the NAS to provide its own resources in support of the collaborative research program funded by A.I.D.". Another reason might be, as reported to BOSTID by an Appropriation Committee staff member, is that

there was a feeling in the Senate Subcommittee on Foreign Operations that the Institute for Scientific and Technical Cooperation (ISTC), which had been killed by the Senate Appropriations Committee after the Vienna Conference, had been revived contrary to the will of the Congress and brought to the NAS by its president, Frank Press (who had promoted ISTC from his position as Science Advisor to President Carter before he became president of the NAS) (Greene, 1991: 123).

This had two immediate effects. The grants that had been awarded in late 1987 had to be retracted and a decision was taken at the highest level of the National Research Council and United States to bring the 
BOSTID program to an end. A.I.D. granted a no-cost extension of the research program grant until January 1992 for smooth completion of the ongoing projects.

In the conclusion of his book, Michael Greene draws the major lessons learned from the BOSTID Grants Program for international cooperation in science development (Greene, 1991:112-25). Among the various obstacles to doing good research in developing countries and the different constraints identified, three stand out:

- Operational difficulties and lack of resources including lack of basic equipment, irregular supplies, cumbersome institutional regulations, uncontrolled laboratory conditions, inadequate library resources, frequent political strikes and changes of policy...etc. While ingenuity of scientists and ad hoc solutions can be implemented to solve some of these problems, other conditions such as runaway inflation are hard to combat.

- The lack of career recognition and reward for excellence is according to Greene, the most serious problem of science in developing countries. Greene argues that "science prizes for excellent research and salary differentials to those who bring in international grants and publish papers in international journals are among the acknowledgements that would help to strengthen the career of a scientist."

- The lack of a true community of scientists that read and discuss each other's work, meet for seminars, exchange ideas, and review each other's papers and proposals.

For BOSTID grantees, the coordination meetings provided highly needed intellectual inputs. In many cases, the assistance and collaboration of U.S. scientists was effective in breaking the isolation, but the collaboration would probably have been more effective if money had been made available to also support the U.S. collaborators.

Grantees in Africa were found to face especially daunting problems. Out of fifteen grants, one was given to the International Council for Research in Forestry, which is not representative of an average African institution. Of the fourteen remaining grants, five resulted in publications in refereed journals (one of BOSTID's criteria for success), three others have produced some unpublished results of value, and five were not considered successful at all. One of the successful African grantees is an expatriate from India. The other successful projects were characterized by strong interaction with foreign scientists-U.S., French, and German. This suggests that until the conditions for research are improved in Africa, the African projects are likely to need collaboration with colleagues from outside Africa.

\section{The U.S.-Israel Cooperative Development Research Program (CDR) ${ }^{28}$}

In 1985, the U.S. Congress set aside US $\$ 2$ million to establish the U.S.Israel Cooperative Development Research Program (CDR). CDR is a new initiative of the A.I.D., which seeks to increase the access of Less Developed Countries (LDCs) to scientific, technical and development institutions in Israel. 
LDC and Israeli scientists and institutions are invited to submit joint research proposals. Grants are for no more than US $\$ 200,000$ in total funding $^{29}$ (usually over 3, 4 or even 5 years). A grant might typically provide about US $\$ 30,000$ a year to two collaborating institutions for three years. The grants are often divided into two equal parts between Israeli and LDC collaborators. Investigators may be from universities, government laboratories or the private sector. Government laboratories that receive grants are required to provide at least 25 percent matching funds. CDR also support collaborative research involving international research centers. Priority is given to research collaboration involving the countries receiving development assistance from A.I.D. The CDR program gives priority to areas in which Israeli expertise could be particularly valuable to LDCs and in which Israeli scientists and engineers have a comparative advantage. These include, but are not limited to: arid lands agriculture, agroforestry, agricultural intensification (including water management and multiple cropping), plant biotechnology, biotechnology related to human and animal:health, innovative use of by-products (e.g., for livestock husbandry), marine sciences and aquaculture, biological control of insects, energy research and studies of global climate change. The management of the CDR program is otherwise very similar to PSTC previously described. As for PSTC, it is administered by the Office of the Science Adviser within A.I.D, which is, as well, responsible for the selection process.

During the three first years of operation (1985-1987), 81 grants were given to projects located in some 20 developing countries. Most of the grants were close to US $\$ 150,000$, with a few around US $\$ 120,000$. In Israel, 80 percent of the collaborative scientists involved were concentrated in four institutions: The Hebrew University of Jerusalem (21), the Israel Agricultural Research Organization (19), the Ben Gurion University of the Negev (13) and Tel Aviv University (11). The remaining grants are spread over some ten additional institutions, including three private institutes. Slightly more than onethird (29) have been approved for projects in Asia (with a clear concentration in Thailand (14) and the Philippines (10)); about one-third (22) went to African institutions out of which ten to Kenyan institutions including four to ICIPE; about one-third (21) went to Latin American institutions (with a slight concentration in Costa Rica and Peru). Nine grants were also awarded for collaborative projects between institutions in Portugal and Israel. ${ }^{30}$

The program was under strong pressure in 1988 and 1989. The Israeli Government had expected to manage the program and decide on grant applications. Realizing that it was not the case, they put pressure on the U.S. Congress to transfer the management of the program from A.I.D. to Israel. A compromise was found whereby the management of CDR remained with A.I.D. and a new program, the Collaborative Development Program (CDP) was established and administered by the Israeli government with an annual budget of US\$ 2.5 million provided by the U.S. government. As a consequence, the annual budget of CDR decreased slightly during the consecutive years (from US $\$ 4$ million in 1988 to US\$2.5 million during 1989-92). An important increase is expected for $1993^{31}$ with an opening of the program to the states of the former Soviet Union. 
CDR was evaluated in 1991 . The main conclusion was that it supports good science but suffers from a number of administrative problems. Among those, transfer of funds to the LDCs partners via the Israeli institutions is probably the most problematic. Another problem is the lack of support from the A.I.D. missions.

\section{The Danish Program for Enhancement of Research Capacity in Developing Country (ENRECA) ${ }^{32}$}

Established within DANIDA in November 1988, the Program for Enhancement of Research Capacity in Developing Country (ENRECA) became operational in December 1989. The main objective of the program is to support a long-term (10-15 years) development of research capacity of selected institutions in developing countries through twinning arrangements with Danish research institutions. The two first ENRECA twinning projects were approved in December 1989, ten projects followed in 1990 and eight in 1991.

-At the end of 1992, the number of active projects was 24; most of which originated from personal contacts between researchers or an already existing research cooperation. So far, twinning arrangements can typically be traced back to former students or researchers from Developing Countries who have received a scholarship to study in Denmark or to already existing agreements of collaboration between Danish and local universities in Developing Countries. There are also funds available for Danish researchers, which allows them to visit developing country research environments in order to meet possible partners.

In addition to scientific quality, relevance of the proposed project and capacity of the participating institutions to carry it out successfully, the main criterion for project selection as defined in "Guidelines for Danida Support of Research Assistance Projects" is its potential to strengthen research capacities in the developing countries (Danida, 1992a and b, Annex). Other criteria also listed range from project agreement with the general priorities as defined by Danida with respect to priority or eligibility of country, research priority areas, ${ }^{33}$ and ethical or environmental concerns. It is stated that priority will be given to countries in which Danida has a permanent mission, ${ }^{34}$ but that other countries may also be considered as long as adequate preparation and execution can be ensured by the participants. Today, the basic rule is that only countries with a GNP per capita lower than US\$ 1,700, may be considered as partner countries. The project guidelines also emphasize that projects must be considered long-term investments (10-15 years), that the support will in general be provided for three year project phases at a time, and that the support for each project phase can normally not exceed US $\$ 500,000 .^{35}$ The initiation of new projects may be facilitated by the allocation of small grants (up to US $\$ 33,000$ ) in connection with the preparation of joint research proposals and, in some cases, the identification of suitable Third World partners for research cooperation.

The 24 projects active in late 1992 are distributed rather evenly between social, natural, health and veterinary sciences as well as technology. ${ }^{36} \mathrm{Geo}-$ 
graphically, the distribution of participating institutions in developing countries shows a clear concentration in Africa (18 projects in eight countries, mainly Tanzania, Ghana and Kenya), while only five institutions are involved as partners in Asia (India, Bangladesh and Thailand) and one only in Latin America (Ecuador). Most twinning arrangements (except for Thailand and Ecuador) took place in Danida's program countries. In late 1992, three-fourth, of the active projects were to be found in Africa (one-fourth of all projects in Tanzania). In Denmark, the distribution of participating researchers is, with three exceptions, concentrated in the greater Copenhagen area and in higher education institutions. The average budget for each project is approximately US $\$ 450,000$ or US $\$ 150,000$ per year. The proposed budgets as well as actual expected expenditures have generally followed the principle that at least half of all expenditures should take place in the developing country. The distribution of expected expenditures on various budgetary items shows that the largest single item is salaries ( 35 percent of the total budgeted amounts), followed by equipment ( 20 percent), travel (20 percent), materials (17 percent), administration ( 2 percent), and other expenses ( 6 percent). It should also be added that close to half of the ENRECA projects benefited also at the same time considerable support from one or more other sources. Among the latter are: UNDP, WHO, EC, World Bank projects, and US and Danish sources including Danida (1992b:30-31).

According to the conclusions reached by the Evaluation conducted during 1992,

the ENRECA program is, in spite of its short existence, already providing valuable contributions to research capacity building in developing countries with high efficiency and a low cost/benefit ratio, compared with many other international efforts in the field. The projects have already produced a large number of disseminated results: a total of 287 research papers of which 41 appeared in international journals and 209 in conference proceedings. Interaction with local users has started in several projects. Research training is performed in all projects; some emphasize formal programs at the Doctoral or Masters level, while others prefer more informal activities. Presently, 26 students are involved in Masters programs and 41 in Doctoral programs. Six doctoral and six Masters degrees have already been awarded (Danida, 1992b:4).

Among the problems encountered the following were considered of being of particular importance:

- The qualifications of the developing country participants have not always met the expectations of the Danish counterparts, even though ad hoc solutions have been found to provide developing country partners full opportunities for participating actively in the research.

- The limited time that most senior researchers can spend with projects participants in developing countries was also found to be a matter of concern. In general, projects have often been dependent on one or two key persons. When they change assignments, projects may suffer severely. 
- In some cases, developing country partners have been active participants in the research activities alone, but much less involved in other phases of the research work, i.e., the planning and dissemination processes.

Implementation of most projects have experienced delays as well as other practical problems, but most of these problems, often of a bureaucratic nature, have been solved through ad hoc solutions worked out by the partners in the cooperation. It was also considered a severe limitation that projects mainly dealt with research areas in which Danish researchers have a need to work in developing or tropical countries, while other important areas so far were almost missing.

\section{The Science, Technology and Development Program (STD) of the European Community ${ }^{37}$}

The Science, Technology and Development Program (STD) was created by the European Parliament in 1982. It is the first program of the European Community specifically devoted to scientific cooperation with Developing Countries. ${ }^{38}$ From the moment it was launched in 1983, the program concentrated on two priorities: tropical and subtropical agriculture; and medicine, health and nutrition in tropical and subtropical areas. The first STD program received 40 million Ecus for four years (1983-1987) and supported 411 projects in 73 countries (of which 64 developing countries). The level of funding was doubled during the second phase (1987-1990) during which 339 projects were approved with partner institutions in 97 countries (of which 86 developing countries). For the third ongoing phase (1991-1994) the budget has been further increased to 111 million Ecus.

The objectives of the program are multifold:

- to contribute to the strengthening of research capacity in developing countries in order to bring them up to the level of excellence required to become full partners, and thereby reducing disparities between north and south;

- create and strengthen sustainable tropical research capacities in Europe as well as to improve synergy between the various European initiatives in the field of R\&D for developing countries; and

- to increase (particularly since STD2) the impact of research on development and to guide research on the tropical environment ensuing its coherence with the Community strategy for development and technological research.

In addition to the scientific quality of the projects submitted, a number of criteria have been developed for selection including:

- the involvement of at least two teams from the Community and one team from the developing countries;

- the contribution of research projects to strengthening the scientific potential of developing countries;

- the regional impact of the solution envisaged; and 
- the extent to which the project complements other Community R\&D schemes.

Today, a typical project involves at least two research teams in Europe (of which one is normally the leader) and at least one team in the South with an average budget of approximately 300,000 US $\$$ for a three to four-year period. The average budget allocated by project has doubled between STD1 and STD2. Many successful projects have been renewed for a second period.

As all European Community programs STD has been evaluated every four years at the end of each phase. The first evaluation concluded in 1987 that the program had been, over a relatively short period, well received in all tropical continents and in particular in Africa. This was however mainly due to the immediate mobilization of the specialized tropical research institutions of the former colonial powers (mainly UK, France and Belgium). This first evaluation report thus stressed the importance of involving other European countries and in particular research institutions that were not specialized in tropical studies. This was found necessary in order to avoid the tendency to reproduce and strengthen former bilateral cooperations. Another criticism also was that the projects were too often initiated by the European partners with the partners in the South playing a rather passive role or no role at all. These recommendations have been largely implemented as shown by the evaluation of STD2 carried out in 1992. Whereas STD1 approved close to one-fifth of the grants to projects carried out by one European partner vaguely connected to an informal network in the South, no such project hias been approved during the second phase. The average number of partners by project has sensibly increased from 2,5 in STD1 to 4 in STD2. This is mainly due to an increased participation of European institutions. At the same time the number of "bilateral projects" have decreased from two-third, in STD1 to one-third in STD2. The tendency of bilaterality remains however relatively stronger in Anglo-Saxon countries. The pluriEuropean constraint introduced by STD has forced the most active researchers and institutions to reactivate some informal networks and to create new collaborative links.

Yet, a number of European institutions are playing a central role. ${ }^{39}$ In the South a small number of partners are dominating the scene and attracting a large number of collaborations..$^{40}$ At the same time there is a clear renewal of STD "clients." One-third of the partners have been renewed between STD1 and STD2. Twelve European countries are now involved in the program, and participation of northern European countries (in particular Germany and Netherlands), and of southern European countries (mainly Spain, but also Italy and Portugal) is increasing. From 1988 to 1992, STD2 has involved about 1,000 teams or laboratories in Europe and in 74 countries in the South, mobilizing close to 8,000 people (of which 6,000 scientist). In the South, half of the partners are concentrated in Africa, mainly French-speaking African countries (Senegal, Ivory Coast, Burkina, Mali) and Kenya. Outside Africa, the main partners are in South East Asian countries (particularly in Thailand); in some strong scientific communities of Latin America 
(Brazil and Mexico); in Maghrebian countries. In the South, the concentration of partners is often correlated to mainstream science production as reflected in the main bibliographic data bases.

European countries are responsible for two-third, of the submitted applications to STD and countries of the South close to 30 percent. Success rates of applications (percentage of leaderships approved/proposed) between north and south are quite uneven. The average success rate is approximately one-fifth with the following disparities: thirty-three percent for European applicants, 12 percent for applicants from the South and 1 percent for the remaining countries. As a result, partners in the South have obtained only 10 percent of the leaderships (15 percent in agriculture, 6 percent in health).

\section{Lessons Learned: What Works and What Does Not?}

The collaborative research programs presented briefly in this report have all contributed, in different ways and with various degrees of success, to a strengthening of research capacities in a number of research areas in developing countries. Most of them have also contributed to a better integration of the scientific partners in the South into the international scientific community, thereby significantly increasing their scientific outputs and visibility. Most programs also recognize the importance of training for the developing countries participants within the framework of the collaborative research programs as an essential prerequisite of research capacity building; funds for research training have been included in the research budgets or have been provided separately, often on an ad hoc basis. Training can take different forms-from academic training leading to a degree, to shortterm training to acquire a specific technique-but a basic rule is that it must be integrated in the supported collaborative research programs. This way thousands of developing country scientists have been trained and have improved their research skills, thereby strengthening their national research capacities.

Most programs under review have provided sometimes important resources to scientific institutions in the North and have helped strengthen their capacity to conduct research of relevance to the Developing Countries. This is however a slow process. At their inception, some of the programs (e.g., IDRC and ENRECA) had difficulties to access the necessary competence in the north to cope with the needs of the South. Other programs had a tendency to attract scientists who saw in them significant sources of funds, but who had only a minor interest in collaborating with developing countries. Conversely, the STD program of the European Community attracted at first mostly scientists from institutions specializing in tropical research (e.g., in the former colonial powers: France, Belgium and the U.K.) who proposed joint projects with their traditional partners in the South; but the same program found it much more difficult to access competence in other countries, whose colonial past is less burdensome, and which have neither the same facilities nor the same inclinations (e.g., Germany, 
itra-

i re-

ap-

zess

be-

ap-

:ent

id 1

ave

e, 6

ave

io a

rel-

ion

im-

bil-

the

ra-

ild-

ets

an

rrt-

ust

ray

ive

ich

re-

en

in-

ro-

try

so-

int

ith

n-

in

ad

he

ie-

sh

cy,

Denmark, Greece). After a decade of operation, the resource base, and probably also the dedication, for research cooperation with developing countries have been significantly increased in most EC countries.

\section{The Widening of the Gaps and the Need for Differentiated Strategies}

The geographical distribution and concentration of the collaborative programs are to a large extent determined by historical, geopolitical and linguistic conditions. The North American programs tend to favor collaborations with Latin America and Asia whereas the European programs have more than half of their collaborative partners in Africa.

Many of the difficulties experienced by the programs are related to the widening gap between developing countries. They cannot be reduced to an homogeneous entity and they are now. frequently listed in several categories: Least Developed Countries; Intermediary Countries; and Newly Industrialized Countries. The recent programs for the states of the former Soviet Union and Eastern European Countries is further complicating the picture. Partners in Africa generally face more difficult problems than their colleagues in Asia and Latin America. This calls for differentiated strategies. Recognizing this need, SAREC is proposing two types of cooperation, according to the level of S\&T development of the partner institutions: "one in which the building-up and strengthening of research capacity is emphasized, and another in which the achievements of research results are stressed" (Bhagavan, 1992:44-45). The first is directed to less advanced countries, the latter to countries with stronger S\&T capacities. At the same time, SAREC recognizes that the borderline between the two modes of support is sometimes difficult to define.

\section{Small is Flexible}

A common characteristic of most programs is that they rely on limited administrative capacities both for the peer review selection and the follow-up activities. The sizes of the secretariat staffs involved are between two and twenty people. ${ }^{41}$ It should be kept in mind that the administration of numerous small or medium-size international collaborative projects is relatively much more time-consuming than the administration of larger research or development programs. The apparent administrative weakness may also, in many respects, be considered as a strength. Most programs must remain small, thereby allowing for more direct communication, more flexibility, and a more informal management style than in many other programs. As a consequence, the motivation and dedication of the staff is also often greater. In critical cases however, some programs would benefit from an increased staff which would improve their monitoring and analytical capacities. Yet, a distinction should be made here between the programs located within a larger bureaucracy (e.g., PSTC and CDR) and those which-because of their NGO status or for other reasons (e.g., BOSTID) - are operating in 
an autonomous way. Many operations, such as grants approval and transfer of funds, take (much) more time in the former organizations than in the latter.

\section{Collaboration between Unequal Partners}

The main problems encountered in the implementation of the programs relate to the asymmetry of the collaboration and the dominance of the partners in the North. This has been recognized as a main difficulty at the inception of several programs e.g., IDRC and SAREC. Both have the policy only to accept proposals originating from (or submitted with) developing countries, and rejecting those originating solely from the North. SAREC experience has been in the main rather negative when the initiative to start the project arised from the Swedish side: "It is an approach that tends to emphasize the priorities of the Swedish side, leading more often than not to friction and controversy between partners in the long run" (Baghavan, 1992). On the other hand, few institutions in the South enjoy a variety of international contacts to be able to initiate bilateral collaborations (multilateral in the case of STD) with institutions in the North. ${ }^{42}$ In that context, identification of suitable partners, initiation of new collaborations and preparation of joint research proposals can be facilitated by the provision of smaller grants, for this purpose, as provided by ENRECA. These pre-application grants should ideally be available to potential collaborators both in the North and South.

The research priorities, as defined by all the programs are mainly development oriented or developing country specific. On the other hand, North and South do not necessarily have the same research priorities. The comparison of the applications submitted by scientists from the North and the South to the STD/CEC program is revealing: In the field of medical research, European scientists proposed to work on a few major tropical diseases, ${ }^{43}$ whereas scientists in the South gave highest priority to preventive medicine and health problems related to the environment, e.g., diarrhea (mainly infantile and juvenile) and nutrition problems. They have also a much stronger interest in health systems (e.g., traditional medicines and health organization) than their colleagues in the North. Similarly, but to a lesser extent, Europe and the Third World have different interests in agricultural research (Waast, 1992:37-43). Given that the main objective of the programs is to strengthen S\&T capacities in developing countries, it may seem logical that many of the programs advocate that "the research priorities of the developing countries ought to determine the scientific content and the directions of the cooperation" (Bhagavan, 1992:39). On the other hand, this may limit the cooperative opportunities with partners in smaller countries in the North, and might also limit the developing countries' access to more cutting-edge research which might eventually have a stronger impact on development.

Another problem is that mathematics and the basic natural sciences, which must be developed to a sufficient level in any country in order to sunnort 
local training and applications in engineering. agriculture, environment and health, are often not included among the cooperative projects (Thulstrup, 1992). A main reason is that the researchers in these fields in the North generally find the reward for cooperation with other researchers in the North much more rewarding.

There also appear to be a division of labor between the partners in the North and South. Generally, developing country partners have been most active in the implementation of the research project, but less involved in the other phases, i.e., the planning of research and the dissemination of the research results. Scientists in the South tend to be more involved with the execution tasks (data collection, field experiment), whereas their partners in the North tend to be more responsible for the conception tasks. This probably is even more true for programs in the scientifically weakest countries in Africa (e.g., SAREC, ENRECA and STD/CEC). As a consequence, it is not surprising that partners in the North tend to publish close to twice the number of papers, and present twice as many papers at conferences than their scientific partners in the South, as in the case of the STD program (Waast, 1992: 95).

\section{Ingredients of Successful Collaborations: Towards a Charter of Partners}

North-South research partnership is conditioned by clear differences in the functioning of scientific activities in the North and South. The programs presented in this paper attempt to reduce these differences in favor of the developing country partners. But the partnership remains a collaboration between unequal partners. One of the determining condition for successful collaboration is that the partners should be equal or at least complementary in many respects. The experience accumulated during the last decade shows that this apparent vicious circle can be overcome if the collaboration is based on a strong mutual interest and if both parties have something to gain from it. It is therefore very important to choose the right partner. Developing country scientists should have the courage to refuse collaboration when the proposed project is not in their scientific interest. Personal friendships among the partners are also important to overcome many frustrations in the collaboration.

Conditions for success may clearly differ depending on the main objectives of the collaboration, e.g., scientific achievements and/or capacity building. Yet, we believe that it is possible to agree on a minimum list of conditions or requirements for successful collaboration that are common to most North-South partnerships. Based on his experience of "successful projects with a history of good cooperation" at SAREC, Bhagavan (1992:41) provides a number of important such ingredients for successful collaboration. We used most of them as a starting list, as much as they were valid for most programs. This list was then completed with other criteria proposed mainly in the ENRECA evaluation (Danida, 1992), as well as in other programs' evaluations (see table 2). 
TABLE 2

The Charter of North-South Partners.

- The collaboration should be based on a strong mutual interest and both parties should have something to gain from it.

- Project proposals should, whenever possible, be drafted jointly and each partner should be associated as much as possible to the important decisions which need to be taken.

- In particular decision on specific instrument purchase should be made jointly and the necessary provision for installation, maintenance and repair should be secured.

- Provision should be made in the budget for a training component and research training should, whenever possible, take place as part of a formal degree program to increase commitment.

- Salaries should be sufficient to ensure a full-time commitment, or completed by supplementary means (e.g., research honorarium) secured in the budget.

- Transparence should be a golden rule between the partners, e.g., both sides have information on the budget allocations to each side and how funds are being spent.

- Each cooperating group should include a substantial number of researchers (at least 3).

- Both parties should meet regularly to review ongoing work and plan future activities.

- Communication channels (e.g., fax and $\mathrm{E}$ mail) must be available to secure efficient interaction between partners.

- Scientific papers should be written jointly, with the names of the authors from both sides appearing on the published articles.

- Collaborative programs should be evaluated on a regular basis, e.g., after each phase is completed. Monitoring should emphasis project outputs, rather than inputs.

- Mechanisms should be established so that the collaboration can continue after the collaborative program is terminated to ensure a long lifetime to the collaborative partnership.

It is suggested that the proposed checklist of ingredients of successful collaboration be used as a charter of partners so that each partner (in the North and in the South) is associated as equally as possible to the different phases of the cooperation from project design and definition to implementation of the research and publication of the results.

\section{Notes}

The author would like to thank Erik Thulstrup for his comments on a draft of this paper. This paper was prepared while the author was a Visiting Fellow at the Center for Interna- 
tional Science and Technology Policy, Elliott School of International Affairs, George Washington University, Washington D.C.

1. Some of the material presented here is included in a World Bank paper under the title: Jacques Gaillard and Erik Thulstrup. 1993. Research Capacity Building through NorthSouth Cooperation: A possible Strategy for World Bank Projects. ESP Background Paper, The World Bank, Washington, D.C.

2. Some of them were created at the end of the nineteenth century. Amongst the most important and best known are (current names): the Tropical Development Research Institute (TDRI) in the U.K., the Institut Français de Recherche Scientifique pour le Développement en Cooperation (ORSTOM) in France, the Royal Institute for the Tropics (KIT) in The Netherlands, the Institute for Tropical Scientific Research (LNICT) in Portugal and the Prince Leopold Institute for Tropical Medicine in Antwerp.

3. Historically, it has had three components: the private foundations, the Agency for International Development (A.I.D.) and its predecessors, and the Land-Grant Universities (Gaillard and Busch, 1993).

4. Canada created the International Development Research Centre (IDRC) in 1970, Sweden created the Swedish Agency for Scientific Cooperation with the DCs (SAREC) in 1975 and Australia created the Australian Centre for International Agricultural Research (ACIAR) in 1981.

5. Most of these programs have been created or strengthened following the UN Conference on Science and Technology for Development (UNCSTD, 1979) during which the concept of S\&T cooperation between developed and developing countries was strongly supported by the developing country representatives.

6. Thus, it has not been possible to include other important programs such as the partnership programs of ORSTOM (France), or GTZ (Germany).

7. Some of these programs have been in operation for a decade or more (e.g., CRSP, STD), and others have been in operation for just a few years (e.g., ENRECA). Some programs consider North-South scientific collaboration as one of their main central criteria for grant selection (e.g. CRSP, STD), others strongly encourage North-South collaborations but do not consider it a requirement for grant eligibility (e.g., PSTC), and others, while exclusively targeting their support to scientists in developing countries have only indirectly promoted North-South scientific collaborations. Because of the size of some participating countries in the North, or because of lack of tradition, some programs (e.g:, SAREC and ENRECA) have a relatively narrow resource base for research cooperation with developing countries, whereas others (e.g., programs in the United States and France) have a much larger pool of scientists likely to participate.

8. This section is mainly based on IDRC reports, in particular Asibey (1992), as well as interviews in Ottawa.

9. Before the recent reorganization (1991), IDRC had seven operational divisions: Agriculture, Food and Nutrition Sciences, Communications, Earth and Engineering Sciences, Fellowships and Awards, Information Sciences, Health Sciences and Social Sciences. Today, the number of program divisions has been reduced from seven to five: Environment and Natural Resources, Social Sciences, Health Sciences, Information Sciences and Systems, and Corporate Affairs and Initiatives.

10. Projects are normally renewed at least one time and could go into several phases of two years.

11. The International Centre for Agricultural Research in the Dry Areas (ICARDA) is the sole recipient of partnership support in Syria.

12. An evaluation framework has been designed including five sub-studies (Asibey, 1992): Study 1: Evaluation of the extend to which Canadian and LDC research partnerships address developing countries research needs and priorities.

Study 2: Evaluation of whether the Canadian and LDC research partnerships have enhanced capacity-building efforts in LDCs. Study 3: Evaluation of transfer of innovations from LDC to Canada. 
Study 4: Evaluation of whether the Canadian and LDC research partnerships have altered the likelihood of the utilization of research results and contributed to development effects/impacts.

Study 5: Evaluation of whether the Canadian and LDC research partnerships have exerted sustainable impact on subsequent research activities/initiatives of Canadian partners.

13. This section is based on Bhagavan (1992) and SAREC (1992).

14. These four major programs are (1) Bilateral Research Cooperation, (2) International Research Programmes, (3) Regional Research Programs and Special Initiatives and (4) Swedish Development Research.

15. These ares are (1) Health and Nutrition, (2) Rural Development and Environment, (3) Natural Sciences, Technology and Industrialization and (4) Social Sciences and Humanities.

16. Furthermore, the bulk of the assistance provided under "social sciences and humanities" in the context of this program is in fact mainly concerning support to central university libraries in Africa.

17. The figures given in this paragraph have been calculated from USAID (1990).

18. In addition to the additional funding provided by the U.S. institution, the CRSP programs are often benefitting from funding from the host institution and other funding programs.

19. As a way of illustration of training outputs, the Bean/Cowpea-CRISP, which has over ten years supported 18 projects, has a long record of training Host Country scientists. During 1980-1990, it was associated with 219 individual degree programs. Of these, 66 were undergraduates and 153 were graduates (97 MSc and 56 Ph.D.). Most (162) of these degrees were awarded in the Host Country or some other developing countries. There were also 899 nondegree participants, 826 of which were from the Host Country or other developing countries (Bean/Cowpea-CRSP, 1991).

20. This section is mainly based on USAID (1992), the Guideline on PSTC distributed by A.I.D. and interviews in Washington.

21. This list includes mainly less developed countries and is regularly updated by A.I.D.

22. Looking at the list of approved projects during 1985-90, Portugal seems to be an exception with four projects. During that period, Portugal, mainly for politico-military reasons, received development assistance from A.I.D.

23. Preproposals are screened initially by the A.I.D. missions and later by the A.I.D. Office of Research in Washington. Successful applicants are given the reviewers' comments and asked to submit detailed proposals for subsequent external review.

24. More grants have been awarded to projects in Thailand than to projects in all of Africa during 1985-1990. This result is partly explained by the active role of the A.I.D. mission in Bangkok and by the fact that a Thai scientist has been recruited to help his Thai colleagues prepare and submit both preliminary and full proposals to PSTC and to monitor the grants.

25. This section is mainly based on Greene (1991) and interviews in Washington.

26. BOSTID has carried out a series of studies on underutilized resources of promising economic value, such as fast-growing trees, tropical legumes and rural technologies. See in particular NAS (1975, 1980 and 1983).

27. Nigeria experienced a particularly low rate of success with only two successful applications out of 27 submitted.

28. This section is based on USAID (1987) and the official guidelines on CDR distributed by A.I.D.

29. The maximum grant size was US $\$ 150,000$ in 1985 , it was raised to US $\$ 250,000$ in 1988 and reduced to US\$200,000 in 1990.

30. During that period, Portugal, mainly for political and military reasons, received development assistance from A.I.D. A relatively large number of strong applications were submitted by Portuguese scientists or with Portuguese scientists as collaborators.

31. Probably US\$ 6 million.

32. This section is based on Danida (1992a), Danida (1992b), ENRECA-Newsletter 1 to 5 as well as personal communications in Denmark and Washington. 
33. The priority sectors of the Danish bilateral aid consist of a broad list of developmentoriented topics including plant production, animal husbandry, forestry, fishery, ecology, health, drinking water, building, physical infrastructure, energy and social science. In addition, it is however stated in the guidelines that "this does not exclude support of basic research"... and that "research within other sectors may be supported in special cases."

34. Danida has a permanent mission in India, Bangladesh and China in Asia; and Tanzania, Kenya, Zambia, Zimbabwe, Mozambique and Sudan in Africa.

35. Project support has occasionally been somewhat higher, but in such cases, the approval of the Chairman of the Board for Danish International Development is required.

36. The distribution given in the Evaluation Report (Danida 1992b:23) is as follows: Biology (29 percent), Health (21 percent), Social Sciences (21 percent), Agriculture (13 percent) and Other Science and Technology (17 percent).

37. This section is based on Waast (1992) and Arvanitis et al. (1993).

38. A second program was also established in 1984 for collaboration with Latin America, Asia and Mediterranean countries only: the International Scientific Cooperation (ISC) activities. It concerns all scientific areas. It has awarded 90 millions ecus during 1984-1991 for 400 research agreements, 26 scientific meétings and 735 post doc fellowships.

39. In Agriculture, this is the case for CIRAD (France), The Faculties of Agriculture of Gembloux (Belgium), Wageningen (Netherlands), CIC (Spain); in health the Instituts Pasteur (France), the Schools of Tropical Medicine (UK); and for all fields ORSTOM (France) or the Institut d'Etudes Tropicales (Belgium).

40. The University of Mahidol in Thailand (Health), The Institut Agricole et Vétérinaire Hassan II in Morocco, ISRA in Senegal, etc.

41. With the exception of IDRC where all the divisions' staff as well as staff from (or located at) the regional offices are also involved. It is however difficult to give an exact figure of the number of people involved.

42. In several of the programs one can single out these few institutions. Examples are the Hassan II Institute in Morocco and some of the Universities in Thailand (e.g. Mahidol, Kasetsart). The two countries have been particularly successful in diversifying their cooperation. This is mainly due to the diversification of their training strategies (Gaillard, 1991).

43. There is also a clear specialization between the countries in the north: French researchers submitted (to STD) a large number of proposals on Malaria, Chagas disease and virology; UK researchers sent in numerous proposals concerning tuberculosis and trypanosomiasis. In areas where competition is less intense (fewer proposals and higher rates of success), Germany has become a specialist in onchocercosis and schistosomiasis, and Holland in leishmaniosis (Waast et al., 1992:37).

\section{References}

Arvanitis, R., Belhadj Merzoug, T. Chatelin, Y., Gaillard, J., Keller, A-S, Meyer, J-B, Schlemmer B. and Waast, R. (1993). Indicateurs adaptés pour guider les stratégies d'un programme de coopération scientifique. Brussels: Commission des Communautés Européennes, DG XII.

Asibey, A. (1992). Evaluation of the effects of Canadian and LDC research partnerships: An evaluation framework, IDRC (International Development Research Center) Evaluation Unit.

Bean/Cowpea-CRSP. (1991). 10 Years of collaborative research on beans and cowpeas. Training Report. East Lansing: Michigan State University.

Bhagavan, M.R. (1992). The SAREC model: Institutional cooperation and the strengthening of national research capacity in developing countries. Stockholm: SAREC (Swedish Agency for Research Cooperation with developing countries).

Burris, R., Carr, C. and Krebs, W. (1985). An interim evaluation of the BOSTID research grants program. BOSTID (The Grants Program of the Board on Science and Technology for International Development of the U.S. National Academy of Sciences). 
Busch, L. and Lacy, W.B. (1983). Science, agriculture and the politics of resenrch. Boulder, CO: Westview Press.

Chrusciel, W. (1988). An evaluation of the biomass resources and conversion module of the program in science and technology cooperation of the U.S. agency for international development. Center for Development Technology. Washington University in St. Louis.

CRSP Council. (1991). The collaborative research programs: Scientific accomplishments and social impacts through joint research and training. Washington, D.C.: USAID/BIFADEC.

DANIDA. (1992a). Desk study of DANIDA's bilateral program for enhancement of research capacity in developing countries. Copenhagen: DANIDA (Danish International Development Assistance, Ministry of Foreign Affairs).

DANIDA. (1992b). Evaluation report: The bilateral programme for enhancement of research capacity in developing countries. Copenhagen: DANIDA (op. cit.).

ENRECA-NEWSLETTER No. 1, 2, 3,4 and 5. Danida programme for enhancement of research capacity in developing countries. 1990-1992. Copenhagen: DANIDA (op. cit.).

Gaillard, J. (1987). Follow up of IFS grantees, 1974-1984. Paper presented at the Fifth IFS General Assembly, University of Panama, 8-14 November.

Gaillard, J. (1990a). Les politiques d'aide à la recherche pour le développement du tiers monde: de l'assistance scientifique et technique à la coopération? ORSTOM, Paris. Cahiers des sciences humaines de l'ORSTOM (3):407-427.

Gaillard, J. (1990b). The future role of the international foundation for science in a rapidly changing world. Stockholm: IFS (International Foundation for Science).

Gaillard, J. (1991). Scientists in the Third World. Lexington: The University Press of Kentucky.

Gaillard, J. and Busch, L. (1993). French and American agricultural science policies for the Third World. Science and Public Policy, London, Vol. 20, 4:222-34.

Greene, M.P. (1991). Research for development: A grants program for the Third World. Washington, D.C.: National Research Council.

IDRC. (1987). Report of IDRC board review panel-Coop. March 17. Ottowa, Canada: IDRC (op. cit.).

IDRC. (1991). Empowerment through knowledge. The strategy of the international development research center. November. Ottowa, Canada: IDRC (op. cit.).

Lewis, J.P. (1987). External funding of development-related research: A survey of some major donors. Ottawa, Canada: IDRC (op. cit.).

Mc Corkle, C.M. (Ed.) (1989). The social sciences in intermational agricultural research: Lessons from the CRSPs. Boulder: Lynne Reinner Publishers.

NAS. (1975). Underexploited tropical plants with promising economic value. Washington, D.C.: National Academy of Sciences.

NAS. (1980). Firewood crops: Shrub and tree species for energy production. Vol. 1, Washington, D.C.: National Academy of Sciences.

NAS. (1983). Firewood crops: shrub and tree species for energy production. Vol. 2, Washington, D.C.: National Academy of Sciences.

NRC. (1991). Toward sustainability: A plan for collaborative research on agriculture and natural resource management. Washington, D.C.: National Academy Press.

OECD. (1985). Scientific and technological cooperation with developing countries. Paris: OECD (Organization for Economic Cooperation and Development).

Sagasti, F., Oldham, G., Vorauri, P., and Thiongane, P. (1983). Evaluation of the international foundation for science (IFS). Stockholm: IFS (op. cit.).

SAREC. (1992). Annual Report 1991/1992. Stockholm: SAREC (op. cit.).

Thulstrup, E.W. (1992). Improving the quality of research in developing country universities. Washington, D.C.: PHREE, The World Bank.

UN. (1979). The Vienna program of action. New York: UN (United Nations).

USAID. (1986). Panel report-national academy of sciences/board on science and technology for international development research grants program. Research Advisory Committee. Washington, D.C.: USAID.

USAID. (1987). U.S.-Israel cooperative development research program: A partnership for international development. Washington, D.C.: USAID.

USAID. (1990). Global research for sustainable food production. Washington, D.C.: USAID. 
lder, CO:

$f$ the proslopment.

s and soADEC.

iearch caJevelop-

iearch casnt of re(op. cit.). Fifth IFS

du tiers M, Paris. ly changentucky. is for the Vashingta: IDRC ielopment major do!: Lessons on, D.C.: hington, hington, d natural s: OECD mational versities. technolry Comship for iAID.

USAID. (1992). Cutting-edge research for development: The A.I.D. program in science and technology cooperation. Washington, D.C.: USAID.

Waast, R. (Ed.). (1992). Indicators and survey of the researchers: Science and technology for development, a European programme. Final Report, EVAK-5126 FR Contract. Brussels: Commission of European Communities, DG XII.

Weiss, C. (1992). Lessons from eight "reforms commissions" on the organization of science and technology in U.S. Bilateral Development Assistance. New York: The Carnegie Commission on Science, Technology and Government, New York (pp. 10-1; 10-35).

Yohe, J.M., Barnes-McConnell, P., Egna, H., Rowntree, J., Oxley, J., Hanson, R. and Kirksey, A. (1990). The collaborative research programs (CRSPs): 1978 to 1990. Paper prepared for the forum on sustainable agriculture and natural resource management, November 13-16. Washington, D.C.: National Research Council.

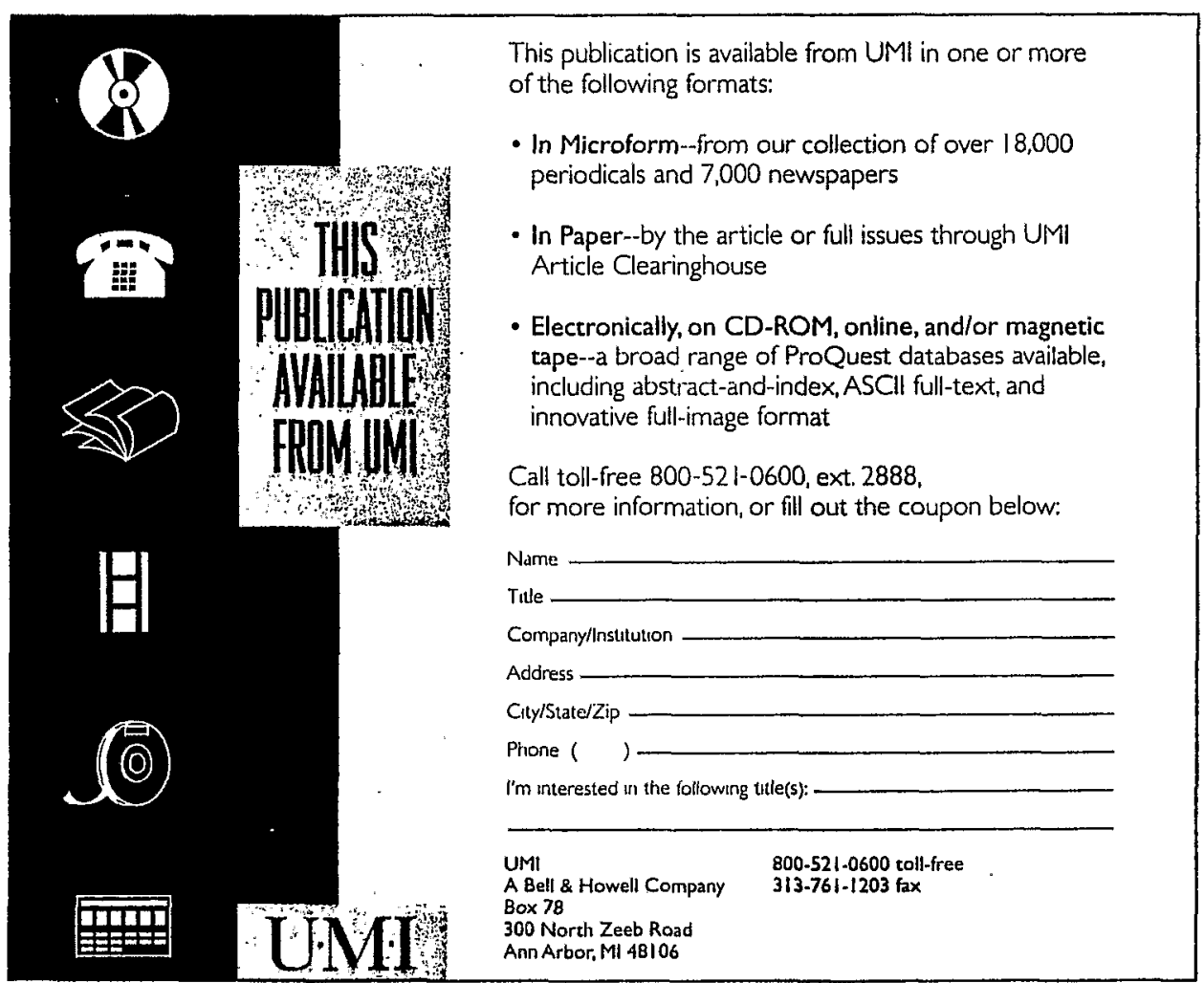

